\title{
Banana Seeds as Support for the Development of New Cultivars
}

\section{ISSN: 2640-9208}

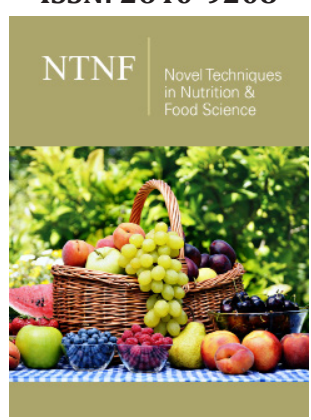

${ }^{* 1}$ Corresponding author: Santos Silva M, Department of Biotechnology, Brazil

Submission: 㘹 June 13, 2019

Published: 制July 02, 2019

Volume 4 - Issue 1

How to cite this article: Santos Silva M,d Novato R C. Banana Seeds as Support for the Development of New Cultivars. Nov Tech Nutri Food Sci. 4(1). NTNF.000579.2019.

DOI: 10.31031/NTNF.2019.04.000579

Copyright@ Santos Silva M, This article is distributed under the terms of the Creative Commons Attribution 4.0 International License, which permits unrestricted use and redistribution provided that the original author and source are credited.

\author{
Santos Silva $\mathbf{M}^{1 *}$ and Novato Ramos $\mathrm{C}^{2}$ \\ ${ }^{1}$ Department of Biotechnology, Brazil \\ ${ }^{2}$ Department of Physiology and Biochemistry of Animal Nutrition, Spain
}

\section{Introduction}

The banana, after rice, wheat and corn is considered one of the most important food sources in the world due to its high energy value, amount of carbohydrates, vitamins (A, B and $\mathrm{C}$ ), mineral salts ( $\mathrm{Ca}, \mathrm{K}$ and $\mathrm{Fe}$ ) ) and low heat levels (90 to $120 \mathrm{kcal} / 100 \mathrm{~g}$ ) and fat ( 0.37 to $0.48 \mathrm{~g} / 100 \mathrm{~g}$ ) [1-3]. According to the Food and Agriculture Organization of the United Nations (FAO), world production of bananas in 2017 was approximately 113 million tons in 5.6 million hectares planted, which shows the great economic importance of banana for food in the world [4]. Several strategies are increasingly implemented to solving problems related to banana cultivation, particularly in relation to the development of cultivars resistant to diseases, nematodes and pests, through biotechnology aligned with the production of agricultural products [5]. Genetic improvement has become a tool whose objective is the selection of superior genotypes within the available germplasm of each species. Through this technique, hybridizations are carried out that objectify the development of cultivars with desirable characteristics for the producer and consumer market, such as vigor, precocity, productivity and tolerance to biotic and abiotic stresses [5].

In the wild, there is a predominance of wild bananas (diploids) in the presence of triploid and tetraploid banana trees. The first case mentioned is about bananas that produce fruits with seeds, while the two following cases are characterized by the production of fruits by parthenocarpy, that is, they are banana trees that generate fruit by natural production or artificially induced without fertilization, which it is characterized as a limitation to be faced with breeding programs [6,7]. In the cultivars of the Cavendish subgroup, like the Great Maine (triploid) and of greater interest in the international market, a high degree of sterility occurs, which makes it difficult to transfer the characteristics of interest of the diploids for these triploids by hybridizations. These cultivars do not produce seeds when they are pollinated with diploids, while in cultivars of the apple type few seeds are produced, which are mostly nonviable [8]. As a consequence of the limitations of banana genetic improvement related to the different levels of sterility of the triploid cultivars, other biotechnological techniques such as genetic engineering, mutation, soma clonal variation, somatic hybridization and chromosome duplication have been applied for the development of cultivars with characteristics desirable and that have good acceptance in the market.

\section{References}

1. Perrier X, Langue E, Donohue M, Lentfer C, Vrydaghs L, et al. (2011) Multidisciplinary perspectives on banana (Musa spp) domestication. Proc Natl Acad Sci USA 108(28): 11311-11318.

2. Borges CV, Amorim VBO, Ramlov F, Ledo CA, Silva DM, et al. (2014) Characterisation of metabolic profile of banana genotypes, aiming at biofortified Musa spp cultivars. Food Chem 145: 496-504.

3. Castañeda NEN, Alves GSC, Almeida R M, Amorim EP, Ferreira CF, et al. (2017) Gene expression analysis in Musa acuminata during compatible interactions with Meloidogyne incognita. Ann Bot 119(5): 915-930.

4. FAOSTAT (2019) Food and Agriculture Organization of the United Nations.

5. Amorim EP, Serejo JÁS, Amorim VBO, Silva SO (2016) Melhoramento Genético. In: Ferreira CF, et al. (Eds.), 0 agronegócio da banana, $\left(1^{\text {st }}\right.$ edn), Embrapa, DF, Brazil, pp. 171-200. 
6. Puteh AB, Aris EM, Sinniah UR, Rahman MM, Mohamad RB, et al (2011) Seed anatomy, moisture content and scarification influence on imbibitions in wild banana (Musa acuminata Colla) ecotypes. African Journal of Biotechnology 10(65): 14373-14379.

7. Silva SO, Amorim EP, Serejo JÁS, Ferreira CF, Rogriguez MAD (2013) Melhoramento genético da bananeira: estratégias e tecnologias disponíveis. Revista Brasileira de Fruticultura 35(3): 919-931.
8. Soares TL, Souza EH, Sampaio LFS, Costa MAPC, Silva SO, et al. (2015) Effect of collection time on the viability of banana pollen grains. African Journal of Botany 14(14): 1207-1214.

For possible submissions Click below: 